\title{
Economic Criticism
}

\author{
NICK VALVO
}

This overview of recent work on the relationship between economics and culture takes the occasion of the Covid-19 pandemic to reflect on the urgency of creative thinking about biopolitics, in the process questioning the utility of apparent divisions between Foucauldian- and Marxist-derived approaches to the question of social reproduction.

\section{I}

An important through line in critical theory of the last decade or so has been an apparent sharpening of the differences between theoretical heritages descended from Marx and those descended from Foucault. The critique initiated in a number of edited volumes by Daniel Zamora and collaborators about a 'neoliberal Foucault', focusing especially on the work that followed the philosopher's so-called 'ethical turn', was instrumental in shaking this conversation out of the footnotes and into relatively popular venues like the Los Angeles Review of Books. (Zamora has, with Mitchell Dean, a monograph on this topic due in 2021 from Verso.) Meanwhile, post-2008 shifts in left energies back towards questions of class, inequality, and precarity, and the simultaneous sharp turn away from the Third Way frameworks grounded in the Anthony Giddensism 'inclusion', gave what might otherwise be a bookish dispute a sense of electoral-political stakes. And indeed, the importance of the debate beyond what might appear to be abstruse questions of the intellectual history of the French 1970 s is actually quite easy to see, bearing as it does on how we are to theorize the relationships between and among the state, the economy, and subjectivity.

The familiarity of anglophone academia with Foucault's Collège de France lectures from 1971 to 1984 has grown only gradually, as Palgrave Macmillan has brought forth its thirteen-volume series of translations into print year by year, under the editorial supervision of Arnold Ira Davidson. 


\section{2 | Economic Criticism}

The development of that familiarity has been an important background factor to the neoliberal Foucault narrative. This reception history intersected in curious ways with the shifting geopolitical valences of the liberal project of a rule-bound and procedural governmentality. Looking back on it all, the trajectory can seem ironic or even bewildering, when we see Foucault blamed by Zamora for a putative turn towards a Chicago-inflected neoliberalism à la Gary Becker only a decade after being accused by Janet Afary and Kevin Anderson not merely of capitulating the European Enlightenment liberal project to the 'seductions' of illiberalism, but of actually fostering the illiberal project of political Islam - surely one of the hotter takes to come from the left in recent decades. It may feel a bit absurd to suggest that a scholarly debate has been in part shaped by the declining salience of the so-called 'Global War on Terror' framework, in part by a collapse of the global financial system that evaporated tens of trillions of dollars in paper wealth, and in part by the release of the English translations of The Birth of Biopolitics and Security, Territory, Population, but here we are.

A 2020 blog post by Peter Coviello, 'Our Man Foucault', stepped back for a moment to consider why Foucault means what he means to his critics on the right and left. Coviello musters less patience than I can for the 'frequently recurring' left critiques 'that bloom and wither like annuals' - 'If you insisted that Jacobin had published some eight or nine of these in the last half-dozen years, each with the identical thesis, I could not find it in my heart to fact-check you' - but his call to see Marx and Foucault as more complementary than conflicting is well taken. The more tendentious versions of the left critique of the Foucauldian project can often feel overwrought and over-focused on the alleged excesses of Foucault's late work while neglecting the massive contributions of his bookshelf of work on institutions, knowledge, and discourse to left-wing thought. And the illustration of that fact that Coviello chooses, a fascinating book in (and, perhaps, against) disability studies by Jasbir Puar, points towards what is worth insisting on in an alliance. Puar's argument in The Right to Maim shows how discourses of disability and minoritized religious status and politicized demography make Palestine into 'a theater of biopolitical experiment', an argument that, as Coviello notes, '[sutures] the project of biopolitical critique to an acute vision of the political economy of global capital, in an era marked both by precipitously decelerating growth and by an environing climate crisis'. Perhaps the Foucauldian and the Marxist can be friends.

In a context in which much of the energy in literary studies may have been shifting away, along Felskian lines, from the entire project of 'critique', the Sturm und Drang on this score feels excessive, especially from the vantage 
point of economic criticism, clearly an area where both thinkers have made immeasurably large contributions. The problem should be thinking through how each tradition can acknowledge and respond to the challenges posed by the other. I think this is indeed happening, even if it is styled as opposition. Much of the Marxist scholarship that presents itself as most ferociously antiFoucauldian seems to this reader to be precisely answering Foucault's challenge to keep the biopolitical dimensions of economic thought in the picture, even if it does so under the guise of differentiating itself from a Foucauldian tradition which it presents as insufficiently radical. If Foucault is more useful to these writers as provocation and foil than as reverent citation, it is not my place to complain.

It was with all of this in mind that I turned to the 2019 collection Foucault, Neoliberalism, and Beyond, edited by Stephen W. Sawyer and Daniel Steinmetz-Jenkins. I was pleased to see much more nuanced and subtle discussions that move beyond reconstructing the blow-by-blow of Foucault's personal political commitments. Granted, Zamora's chapter, 'Finding a "Left Governmentality"', is useful for just that: a careful recounting of Foucault's rightward turn, built like a prosecutorial case: Foucault's vote for Mitterrand in the 1974 elections, but not in 1981, and so on. This level of detail helps him to emplace Foucault's turn within broader currents on the French left in the 1970s - his relation to the left environmental thinker André Gorz, but also to the French 'Second Left' described by Patrick Viveret and Pierre Rosanvallon, a left focused less on the institutionalism of state and labor union and more on minority rights and feminism. What emerges from this case is Foucault's view that France lacked a 'problematic of government', possessing instead only a 'problematic of the state' (p. 58). This helps clarify the nature of Foucault's concern about the Union of the Left, the alliance of ultra-leftists, communist and socialist parties that eventually brought Mitterrand to power. He wrote that there was not, in the early 1980s, an 'autonomous socialist governmentality', and in the process theorized the totalitarian disasters of the twentieth century as the mismatch between a residual governmentality and an emergent socialist political project. Zamora thus helps us see the origins of Foucault's late interest in neoliberalism, if indeed that is what it is, and its continuities with his avowed leftism in earlier decades.

Zamora's chapter removes Foucault from Anglo-American political narratives, even those that he himself invoked in his readings of Becker, and restores him to French conversations about political economy. What we gain - or at least what I gained - from this re-narration is an attenuation of the left-or-neoliberal question, in a way that made his political evolution 


\section{4 | Economic Criticism}

more coherent and comprehensible by providing some of the scaffolding that allows us to consider what it meant for a man of the French left to invoke Becker in the late 1970s. In this light, I want to grant special mention to two of the contributions that I found the most surprising and exciting; no slight is intended to any of the others, which are uniformly worthwhile. The first of these is by Luca Paltrinieri: 'Neoliberal Selves: Human Capital Between Foucault and Bourdieu'. This piece ably sets up Foucault's reading of Becker as an attempted revision of Bourdieu's critique of the human capital concept. Looking back from the midst of the linked behavioral and empirical turns in economics, Bourdieu's mid-1970s critiques of the Chicago school's mathy Walrasianism seem prescient. Human behavior is too constrained by path dependencies imposed by the habitus - the customs, ingrained skills, traditions, and habits that shape and constrain our choices and shape our social lives - for the deviance of returns on human capital from some theoretically ideal outcome to be decried as pathological or irrational. People make pragmatic judgments about how to maximize their human capital on the basis of what they know and feel to be appropriate in terms of morality, taste for social continuity, or appetite for risk, all of which are culturally given. Thus, the neoliberal utopia imagined to spring from emancipating individuals from the regulatory state faces other, perhaps more durable, constraints, and only some of what is solid melts into air.

It is against the background of this economic-sociological critique that Foucault's intervention is legible. For Foucault, Paltrinieri argues, the innovations of liberalism and then neoliberalism are precisely moral-they are less about policy and more about an anti-Kantian revolution in morality as regards the self, and social reproduction (more on that in a moment):

Thus the family is the object not only of love but also of strategies of reproduction is a very old idea, but that these strategies can be calculated and framed in utilitarian (and I would add hedonistic) rational terms - that the children can be treated as consumer goods - is a remarkable innovation not only in terms of governmentality but also in terms of morality. Investment in oneself and one's offspring becomes, in a certain sense, the moral background against which ethical strategies of neoliberal subjectivation are possible. (p. 170)

In other words, while Bourdieu had suggested that Becker et al., had innovative policy proposals that nonetheless did not adequately consider the inertial character of the habitus, Foucault's interest in Becker is precisely on the basis of a recognition that his neoliberal economic thought might have 
some kind of obscure purchase at that profound level. Foucault adopts and adapts Bourdieu's critique, but implicitly suggests that Bourdieu may be overlooking just how thoroughgoing the Chicago school's social thought actually was. And in a most fascinating conclusion to the chapter, Paltrinieri reads Bourdieu's work from the 1990s as incorporating Foucault's critique into his own earlier work, even as the citations go to Polanyi, Veblen and Hirschmann, chiefly in and through his revisions or iterations on the concept of habitus (p. 172). The habitus developed in that work into a kind of reservoir through which the accretion of historical change became available to social action in the present as a kind 'structural unconscious', in tension with economic modes of rationality that promoted a kind of erasure or forgetting of this history. And it is this turn that motivates Bourdieu's celebrated work on social class, which Paltrinieri praises as describing 'the mechanisms of neoliberal competition more thoroughly than Foucault' (p. 173). Again, Paltrinieri achieves this by setting Foucault's engagement with Chicago school neoliberalism into the history of French social thought in the 1970s, restoring the implicit citations and subtextual interventions that his lectures were making, whether consciously or otherwise.

Claudia Castiglioni's contribution, 'Foucault, Neoliberalism, and the Iranian Revolution', achieves a similar effect, but puts the archive of Foucault's essays and opinion pieces on the Iranian Revolution and political Shi'ism in conversation with the Collège de France lectures in order to illuminate both. Foucault and Iran is something of a burgeoning field which has attracted numerous contributions since the Afary and Anderson piece discussed briefly above. Castiglioni both provides a helpful overview of this work and perceptively draws out the ways in which the very criticisms that the philosopher's laudatory commentary on the Islamist project have drawn from right and left show us something about the nature of his interest: that something in this revolution was indeed new, transcending the framework of left and right. Strikingly, Castiglioni, in conversation with Melinda Cooper, one of her interlocutors in the piece, focuses in on Foucault's perception that the Iranian Revolution marks a return to a new vision of the Greek concept of oikonomia and its related notion of the inviolability of the oikos, the household, as a cell of political life. Foucault saw this as a kind of ethical culture at once distinct from the neoliberal entrepreneurial self and the masculine vision of workerist social democracy that is sometimes named under the rubric of a Fordist Family Wage. And so his interest in the Iranian Revolution is at once a sign of his distance from both the socialist tradition 


\section{6 | Economic Criticism}

and the neoliberal vision: it reflects an eager appetite for novelty in governmentality.

This brings us to the larger point that I was hoping to make by raising this debate about Foucault. To me, the problems named by the 'neoliberal Foucault' debate are all also named under the rubric of social reproduction theory (SRT). That tradition has roots in the Marxist-feminist writers and movements of the 1970s and 1980s, especially Mariarosa Dalla Costa and Selma James's 1975 The Power of Women and the Subversion of the Community and the Wages for Housework movement associated with Silvia Federici, among others. Both of these conversations are conducted about many of the same themes on much of the same terrain: both concern the relationships between and among economic life, material life, and selfhood; kinship and sexuality; care, cooking, cleaning, and everything else necessary for well-being; and morality and the motivations for social action. Only the narrative roles these concepts are supposed to play differ: for the Foucault of the Collège de France lectures, a concern for the biopolitical is a prominent signpost of the arrival of liberal governmentality, while for social reproduction theorists, care and reproduction emerge as potential flashpoints for a class struggle that might someday bring liberal capitalism to its knees. The emphasis is placed quite differently.

But for whatever reasons, these conversations are by and large conducted separately. This is a mistake, one whose urgency the Covid-19 pandemic only heightens, by making the dependence of economic activity on medical care, childcare, and eldercare nakedly clear. It has also, tragically, dramatized just how close to the breaking point the systems for provisioning that care are in many societies, and revealed starkly the bio- and necropolitical dimensions of state power.

A recent edited collection, Social Reproduction Theory: Remapping Class, Recentering Oppression, edited by Tithi Bhattacharya, is an able introduction to the SRT tradition. I would especially point readers to Nancy Fraser's chapter, 'Crisis of Care? On the Social Reproductive Contradictions of Contemporary Capitalism', which had already made a splash upon its first appearance in the New Left Review. The key to her presentation of SRT is crisis theory. In the crisis theory associated with classic nineteenth-century Marxism, economic relations were deemed infrastructural, and thus the potential origin of a revolutionary crisis that would be (by definition) capable of meaningfully altering the relations of production. Literary and cultural historians sometimes elide the polemical importance of this point, because we are so often focused on Marxism as a useful framework for theorizing causal relationships between society and culture. But the purpose 
of a base-superstructure model was to help a socialist militant recognize which crises have revolutionary potential. Political crises? No-governments, even constitutions, come and go without meaningfully changing the relations of production. Cultural crises? Same answer. Developments in the arts and even religious Great Awakenings are epiphenomenal in this framework. But economic crises? Yes.

Thus Fraser's choice of crisis theory as the angle of approach for clarifying what social reproduction theory contributes to an orthodox Marxism is quite useful. Classically, care work is seen as 'unproductive' work that aids the productive process only at one remove, by making it possible to reproduce the labor power of that part of the working class engaged in production by doing the often feminized work of feeding, cleaning, caring, birthing, raising, and educating: in the shorthand, the work of social reproduction. This work is at once obviously essential to material existence, but also generally unwaged or low-waged in comparison to productive work. Fraser therefore positions social reproduction as infrastructure's infrastructure. Just as the various superstructures - law, civil society, religion, culture - are reliant on the stability of infrastructural relations of production, the stability of those infrastructural relations of production is in turn reliant on continuities made possible by social reproduction. You cannot, after all, have wage labor without wage laborers, and you will soon run out of wage laborers if they are not fed, cared for, and educated. It should be said that the primary concern of the ensuing century-plus of 'Western' Marxist theory has been in complicating such reductive base-superstructure models, in order precisely to argue how contradictions emerging elsewhere in a social totality can and will provoke true crises with revolutionary potential in the economic base. In that sense, Fraser's intervention (and SRT's more broadly) is just another lap around that track. Even if so, this is a version that reaches directly into the biopolitical dimensions that Foucault taught us are essential to the logic of our neoliberal moment, which feels important in an age of pandemics and looming environmental catastrophes.

The most thrilling chapter in the volume is Susan Ferguson's excellent exploration of the figure of the child under capitalism, 'Children, Childhood, and Capitalism: A Social Reproduction Perspective'. I admire the sensitivity of her account, which avoids both a neo-Rousseauvean Romanticism and an unduly reductive cynicism about childhood as a space of freedom. Instead, she dramatizes the complexity, dynamism, and contestation of the child, who in his/her/their actualization within the capitalist modes of kinship forestalls the actualization of other, different, possible childhoods. And she remains alive to the way that children are at once 


\section{8 | Economic Criticism}

the object of hundreds of thousands of hours of reproductive labor but also agents. I do not believe she actually refers to children as the Lukácsian subject-objects of social reproduction, but that would be how I would summarize the spirit of her contribution. (Ferguson also has a recent monograph I learned about too late to review here, Women and Work: Feminism, Labour, and Social Reproduction.)

Ferguson's chapter thus avoided the pitfalls that some SRT-influenced arguments fall into, and which have led some critics, such as the economist Kirsten Munro, to criticize the entire framework. In particular, Munro is skeptical of some flavors of SRT that try to distinguish between social reproduction, whose meaning they thereby limit to the physical production of another generation of human beings, from societal reproduction, which in this usage designates the class structure, the gendered division of labor, racialization, and other phenomena that make up the relations of production. For Munro - as, I believe, for Fraser and Ferguson - the whole point of the enterprise is to see how reproduction is a contested sphere that implicates broader social relations and in and through which those social relations can and do reproduce themselves. But reproduction also offers a chance for these social relations to evolve, or even to be radically reconceived. To do otherwise is to participate in, rather than critique, neoliberal biopolitics. Efforts to ameliorate social reproduction in service of the maintenance or sustainability of those social relations are misconceived, and may even curdle into variants that aim at the active preservation of exploitative social hierarchies: the White Power movement's notorious 'fourteen words' - a slogan about the preservation of racialized kinship in the face of perceived threatscould classify as SRT in the sense that Munro is critiquing.

Elsewhere in the volume, there are a few chapters that pursue a polemic against intersectionality theory that seems unproductive to this reader, but, that aside, it is a timely and important contribution. Without going into undue depth on those polemics, it could feel almost as though SRT scholars, by arguing for their framework over an intersections-of-oppressions framework for those seeking a more comprehensively socially engaged feminism, are underselling what looks to me like a considerable potential for complementarity between these approaches. The work seems to point us towards a recognition akin to that found in Melinda Cooper's Family Values: Between Neoliberalism and the New Social Conservatism, a book that has so quickly become foundational to many conversations about neoliberal political economy that I was startled to realize it was still new enough to warrant inclusion in this review essay. Cooper argues that while our current-day neoliberal political arrangements present themselves as aimed at the autonomy of the 
individual, they often do so either in the service of or by means of upholding patriarchal family relations. The welfare state and waged care work - especially childcare - are in this way rhetorically aligned against a sentimentalized domesticity and unwaged maternal labor and the social integrity of the nuclear family supported by a single income. Cooper points to this as an explanation for the coalition between what one might see as the Schumpeterian economics of neoliberal political parties, their eager endorsement of 'creative destruction', and a social conservatism that purports to uphold tradition. It makes sense when you add the third leg of the triad, the welfare state, and note that the creative destruction comes at the expense of the welfare state and as such can be presented as a preference for the continuity of patriarchal social relations, and through them racialized modes of kinship. But in general, Cooper reminds us that each vision of individuality necessarily carries with it a configuration of kinship, gender, race, religiosity, and class. The individuality of neoliberalism is a stalking horse for the continuity of a more robust sociality, indeed a biopolitics.

While social reproduction theory begins from the recognition as infrastructure of unwaged care work, care and reproductive work is, increasingly, waged - but not, generally, waged terribly well. As the economist Philip Baumol taught us in the 1960s, another name for deindustrialization is the growth of the services sector. In a climate where many goods and services are becoming less expensive due to containerization and exploitative global supply chains, work that must be done in a particular place and can only marginally improve its efficiency will tend to become relatively expensive. The boom in the non-profit sector of 'meds and eds' highlights this dynamic. As many of us know intimately, no matter how much technology one throws at the problem, one can only grade so many essays in an hour. The same phenomenon is true of work like nursing and childcare, or Baumol's locus classicus, hairstyling. If manufactured products like cars and computers decline in price relative to this kind of care and reproductive work, that work will necessarily rise in price. That is a corollary of the arithmetic of an inflation index.

But the links between deindustrialization and care work can be described with more qualitative nuance than Baumol's mathematical demonstration suggests. These dynamics have been explored in recent work by the historian Gabriel Winant, whose monograph The Next Shift: The Fall of Industry and the Rise of Health Care in Rust Belt America considers how the shift from heavy industry to 'a care economy' has changed the city of Pittsburgh, Pennsylvania, once the center of a booming heavy industrial region noted for coal and steel production. In effect, the care economy in modern 
Pittsburgh means mostly low-wage, mostly female, mostly non-white nurses caring for retired, mostly white, mostly male former coalminers and steelworkers in hospitals and long-term care facilities. This is a remapped vision of the working class, but as Winant explores and as Fraser would lead us to expect, it is nonetheless a new working class ripe with political possibilities. Relatedly, the sociologist Rachel Dwyer has powerfully analyzed the distributional consequences of the turn to a care economy, finding that a shift to care work produces a few high-income opportunities and many low-income opportunities, but does not support nearly as many of the middle-income workers as an older productive economy would have done. This implies that a shift of labor power from the traditional productive economy to these kinds of care economy jobs will tend to produce more inequality, ceteris paribus. The experience of Covid-19 has put these questions of the material and social preconditions for economic activity front and center, and given all of these studies of the economics of care work a somber character.

One of the more interesting programmatic statements of left economic thought in the time of Covid-19 came from Panagiotis Sotiris in an essay in Historical Materialism. 'Thinking Beyond the Lockdown' brought together many of the questions of SRT and ecological discourses of crisis, and, thinking within a Foucauldian rubric, called for the urgent development of a 'democratic biopolitics' that would seek to learn from and respond to the lessons that Covid-19 has taught us at such grave cost about the inequities and institutional failures that characterize most of our societies. While 'one might suggest that because of this association Foucault makes between biopolitics (and biopower) and the emergence of liberal (and neoliberal) governmentality', biopower is in some sense incompatible with democracy, Sotiris thinks that this kind of straightforward denunciation of the biopolitical dimension as such is no longer an adequate basis for a left politics. Such a view

misses the dynamic and relational character of Foucault's notions. Both disciplinary power and biopolitics refer to the modalities of power associated with the emergence of capitalism. Disciplinary power points toward the social production of 'productive subjects' and of a labour power able to adapt to capitalist exigencies of productivity, whereas biopolitics, biopower and governmentality expand and transform this conception in order to incorporate the expansive new forms of sociability and politicity associated with capitalism becoming the dominant mode of production, thus creating a terrain that is by definition antagonistic. (p. 23) 
In other words, social reproduction is the terrain of class struggle and could be the site of a revolutionary crisis. But this requires a left biopolitics that answers or responds to the nationalist right and neoliberal center. Surely this is an urgent project today.

But what does social reproduction mean for economic criticism? The analogy between the kind of care work dramatized by SRT and the forms of non-productive, unwaged, or otherwise decommodified work generally classified as aesthetic is explored in Leigh Claire La Berge's Wages Against Artwork: Decommodified Labor and the Claims of Socially Engaged Art, a book that takes its place in the very interesting recent aesthetic turn in left cultural criticism most prominently exemplified by Sianne Ngai. La Berge begins from the recognition that one central tendency in artworks and artistic practices in the twenty-first century is social engagement. Socially engaged art practices now actively reject any ideological function or even the production of an artwork with exchange value, but instead try to somehow perform the work of social change themselves: the project of critique is still present, but artists now go beyond critique to issue demands, and even try to enact utopianism on a small scale. In short, they try to enact a crisis of social reproduction.

This is a vision of the aesthetic that makes no pretense of autonomy from political considerations or instrumentality. La Berge suggests that this turn in the arts has gone hand in hand with a severe decommodification of the labor of art workers themselves, i.e. the collapse in the wages available for workers in the arts and the culture industry, and in the economic viability of cultural institutions. For this reason, she looks at artworks authored by those constitutively unable to be waged - art students, children, animals, and so on - and considers the kinds of claims they are able to make. An example is her treatment of an art project called Haircuts by Children by Mammalian Diving Reflex, an artist collective. In a sense, the materiality of this art piece is an act of child labor:

Haircuts by Children has been staged globally over the course of ten years, and in each of its iterations children become - for a few days, anyway - wage laborers. In the performance MDR collaborates with a hair salon and a primary school over a series of weeks to train a group of between twenty and thirty children in the skill of haircutting. After a series of workshops about the history of socially engaged art, in which they will soon be partaking, as well as vocational training with hair stylists, the participating children take over a haircutting salon for a weekend, during which they commit to four- to five-hour staffing shifts. Publicizing their availability with 
hand-drawn posters, the children and MDR make available free haircutting appointments to an adult public who show up and allow their hair to be cut by a group of children. (p. 186)

The piece is a play of commodification and decommodification: paying people one is not supposed to pay for work, done for free, that one is supposed to pay for. The results of these performances dramatize the importance of care work like barbering as social reproduction. La Berge quotes one of the artists, Jenna Winter: 'The first time I got my hair cut [by children]: I was like: oh my god! For artists [it's] ok, but for other people, they have to live in the world and go to their jobs' (p. 186). La Berge notes that many of the adult customers are retired senior citizens. In a way, what Mammalian Diving Reflex has done in this piece is stage a smallscale crisis of social reproduction, by paying people who are supposed to be definitional non-workers to care for the bodies of others in such a way that would disqualify those others from productive labor. In this way, the piece stages an affinity between art and care as marginal to the productive economy.

But the larger point of the book is to complicate any simple boundary between productive and non-productive economic activity. SRT is not mentioned explicitly - it almost doesn't have to be, given that the title is a riff on Federici's classic text - but La Berge's argument nonetheless serves in my view as a productive model and stimulus for an economic criticism that used SRT to raise the question of the place of the economic within a broader social field. She does so by-contra Foucault, whom she dismisses as neoliberal - recentering the question of labor, even as and in spite of her recognition that (in Mario Tronti's words) 'the social character of production has been extended to the point that the entire society now functions as a mode of production' (qtd. p. 23). She does this within a real subsumption framework, i.e. a focus on how processes of valorization can be dispersed broadly throughout society, even as certain productive activities - aesthetic activities in her argument; care work in SRT — do not yet or can no longer command a wage. 'Decommodified labor may be understood as one experience of real subsumption. On the one hand, we can't stop working; everything seems to be able to produce a profit. On the other hand, labor that is waged has been in retreat. We can't stop working and we can't seem to get paid for the work that we do' (p. 24). But, as she concludes, this development has grave consequences for an aesthetic tradition that wants to set art on a pedestal as the Schillerian exteriority to production: productive in its very renunciation of productivity. 
All of these works help to remind us of the central tension in the idea of the economy. It is, on the one hand, a realm of human social action, and one with a boundary, that might allow people to speak of economic and noneconomic phenomena in the way that one might talk about domestic, artistic, religious, or humane spheres of freedom set aside from and impenetrable to economic motivations and the depredations of marketized society. But 'the economy' also names the emergent character of all social life. Thus the econometricians track the waxing and waning of our domestic impulses under the rubric of household formation. At least since Marx, we've understood how the dynamics of capital formation involve just this kind of exteriorizing of, say, the religious sphere or women's domestic work or, indeed, the aesthetic, beyond the play of capital formation, only to reincorporate them in a later phase of development. New work on art, culture, and religious thought during the formative years of the neoliberal order grants us new insight into this process in progress, allowing us to ground this historical process in the institutions, networks, and personalities who brought it about.

One of the more disorienting developments in the last thirty-odd years of cultural history has been the repeated disclosure that many of the institutions responsible for promulgating midcentury highbrow culture in the West, with its neo-Kantian vision of a disinterested or autonomous aesthetic realm, were, to greater or lesser extent, secret organs of the American security state. The documentarian Frances Stonor Saunders, in The Cultural Cold War: The CIA and the World of Arts and Letters, and Eric Bennett, in Workshops of Empire: Stegner, Engle, and American Creative Writing During the Cold War, argued that, through vehicles like the Congress for Cultural Freedom, the CIA supported highbrow magazines like the Paris Review, underwrote touring exhibitions of giant abstract expressionist canvases that would otherwise have been prohibitively expensive to transport and display, and even influenced the Iowa Writers' Workshop, that tentpole institution of American literature of the Program Era. The geopolitical aim was both simple and-given the CIA's role-deeply ironic: to mark the contrast between the purported freedom and independence of American intellectual and cultural life and that of the Soviet Union, whose avantgarde early decades of aesthetic experimentation had largely been brought to heel by Andrei Zhdanov in the immediate postwar period. Taken together, these studies are re-embedding putatively disinterested twentiethcentury cultural developments in the institutional connections, personal 
networks, and interests that made them possible. Pamela M. Lee's Think Tank Aesthetics: Midcentury Modernism, the Cold War, and the Neoliberal Present is a major contribution to this research agenda. Her topos is the think tank, which, as a site of intellectual production is inevitable for this argument, because, as a scene of research shorn of even the pretenses of disinterest that prevail on, say, the campuses of an R1 or red brick research university, it has a relationship to scholarship not so disanalogous to the relationship public relations bears to journalism.

Lee's book is a challenging one to summarize, as it looks closely at the intellectual networks and habits of thought that linked the new institutions of the rule-based neoliberal order with their cultural concomitants. So I will settle for describing the second chapter, which I found the most compelling. It looks at how the aesthetic principles in Boazian anthropology - the idea of culture as a pattern, a curiously perceptual figure - connect the anthropology of midcentury heavy hitters like Margaret Mead to the reception of abstract expressionism, with a focus on Jackson Pollock. But the argument gains heft because she is able to reconstruct some networks and relationships that tie the work Mead and others were doing in the years around 1950 on behalf of the RAND Corporation - a hawkish think tank underwritten by the defense contractor Douglas Aircraft and helmed by the United States Air Force General Curtis LeMay - to figures in the New York gallery scene, both emphasizing personal connections and noting shared intellectual concerns. The particular focus is a study by Mead on Soviet Attitudes Towards Authority (RAND, 1951), an appropriation of cultural anthropology for purposes of grand strategy completed by a scholar who neither spoke Russian nor had visited the USSR. This study, as well as a simultaneous multi-authored project based at Columbia University and supported by the US Navy called The Study of Culture at a Distance, promised to support strategic insights by recognizing 'cultural regularities in the character of individuals [...] inaccessible to direct observation' (p. 91). To do this, Mead and these other anthropologists relied on 'projective' methods such as recording subjects' responses to inkblots and asking them to complete drawings based on abstract template prompts. If nineteenth-century comparative anthropology was the intellectual sustenance for a Civilizing Project of empire, a power ranking of global cultures by their intellectual sophistication, the new relativism and respect for cultural difference that characterized Mead's research gave support to a different geopolitics.

Abstraction is cryptic, murky, and occult. During the early years of the Cold War its projected meanings could not help assuming a 
military aspect. Scholars commissioned by RAND would marshal their diverse expertise in reading analogous patterns, bridging the divide between art and a broader visual culture, and between the humanities, social sciences, and hard science [...] For an exhibition staged at the Museum of Modern Art a few years earlier, [Margaret Mead's husband, the anthropologist] Gregory Bateson wrote what would amount to a prophetic statement for the year that concerns us: 'There is one common ground between the scientific world of the anthropologist and the world of art: the idea that in some sense the artist expresses himself. [...] In a time of war [this idea] may become as grim as a mathematical equation in ballistics. (pp. 126-27)

The calipers may have been set aside, but now the national characters of geopolitical others were to be discerned by aesthetic means in so-called 'Culture and Personality' studies. Aesthetic experience will disclose something of the unconscious mind, which, when aggregated, will reveal a pattern to a trained observer. That pattern is called culture.

Turning our attention to the other side of the Atlantic, one of the longstanding political realities in the European Union is the place of a particular approach to economic policymaking - the variant of neoliberalism known as ordoliberalism. The ordoliberals were friendlier to the maintenance of existing familial, social, and legal structures even amidst their commitment to trade liberalization and fiscal restraint. But it was not always thus. The pathway to power that the ordoliberals eventually found, curiously, was through rapprochement with post-war Catholic political parties: in other words, Christian Democracy. In their moderation, Christian Democratic parties can seem less distinct, more a hazy background phenomenon of the postwar zeitgeist, even as they have been wildly electorally successful in a number of countries. Actually understanding their politics as part of a longer tradition that construes economics and culture and historical consciousness in a very particular way is the aim of James Chappel's notable Catholic Modern: The Challenge of Totalitarianism and the Remaking of the Church.

The book traces the roots of Christian Democracy to early twentiethcentury Catholic conversations about modernity, chiefly in France, Germany, and Austria. The nostalgic, conservative Catholic politics of Church and Crown that still prevailed into the 1920s had no obvious future after the First World War swept away the Catholic empires that that politics was supposed to uphold - even if many adherents felt that the calamity of the Great War was precisely the result of the secularism that they lamented. The rise and fall of fascism over the subsequent decades left the Church 
eager to downplay the antisemitism of some of its earlier traditionalisteven neo-medieval-political commitments. So Catholic traditionalism was out, and thus a new Catholic politics that might reflect a coherent approach to modern liberal state forms with formally secular political institutions. This meant renouncing the integralist goal of the Catholic capture of state institutions, and coming instead to rethink political Catholicism for its new existence in the private sphere-elaborating a new pluralist, even liberal, politics of religious liberty, economic management, and human rights.

Even conservative Church leaders came to speak this new language fluently. In the 1930s and during World War II, Pope Pius XI and Pope Pius XII [...] began to emphasize modern themes, which had been almost entirely absent from Church leadership discourse in the 1920s. In the place of the rights of the Church, they spoke of 'human rights'. In place of the dignity of the Church, they spoke of 'human dignity', which accrued to all people, not only to Catholics. And in place of Catholicism's privileged place in the polity, they began to speak of 'freedom of conscience'. (p. 61)

But as Chappel demonstrates, there were competing visions of what this new political Catholicism might be and how it might work. He classifies these as 'paternal' and 'fraternal' visions of Catholic modernity. The paternal model was more conservative, emphatic in its anti-communism, and aligned with the kind of right liberalism of a Wilhelm Röpke. These movements in political Catholicism often sought accommodation from the fascist regimes of the 1930s and onward, which they appealed to in liberal terms for protection of the private sphere of human dignity and rights. This move came even from Catholic intellectuals who joined fascist parties. 'If paternal Catholic modernism was not inherently fascist, it was not inherently antifascist either' (p. 67). They were willing to collaborate with fascism, which they saw as only one of the odious forms of the secular modern state, if and when it served their higher aims: namely, the preservation of patriarchal social relations and the integrity of the family as the institutional space in which that private sphere of human dignity could manifest, as the last bulwark against the atomizing totalitarianism of modern state forms right and left. This is a politics of social reproduction, akin to that diagnosed by Melinda Cooper in American evangelical contexts, or along similar lines the Catholic 'Navarra school' of neoliberal political economy recently identified by Bethany Moreton, which she proposes to set on the shelf alongside the neoliberal thought collectives already recognized in Geneva, Freiburg, Chicago, Virginia, Vienna, and Cologne. In all cases, the question is the 
maintenance of a vision of marriage and the reproductive family that might serve to make possible the continuity of the Church. Modernization, in this sense, means a retreat from Catholic-held political, social, and cultural institutions to the stronghold of a Catholic family life. This politics pointed the way to a Catholic neoliberalism, a Catholic biopolitics, and even a Catholic eugenics, some of it in the service of a rehabilitated antisemitism.

The second, 'fraternal', tendency was more clearly animated by antifascism, and aimed at the restoration of civil society - especially trade unionism - and internationalism. This group feared that the coming war might find the Church 'on the wrong side of the barricades', as the German antifascist Walter Dirks suggested in the early 1930s (p. 111). Many of the key figures were either exiles during the war years, often in the United States, or else members of domestic resistance movements. While not precisely socialist in orientation, this fraternal Catholic politics was humanistic and proworker.

Just as Catholic anti-Communists were not generally dyed-in-thewool fascists, Catholic antifascists were not committed Communists. There were some who believed that Catholicism and Marxism could, in some theoretical way, be combined, but this was rare. More commonly, Catholic antifascists maintained an opposition to Marxist metaphysics and Soviet politics while hoping that this would not preclude collaboration with workers' movements on worldly issues in a spirit of brotherhood. (p. 109)

But as Chappel explores at length, this politics is curiously contradictory and strange. He profiles Jacques Maritain, a leading Catholic intellectual connected to the French Resistance, whose 1936 book Integral Humanism was the major document of this tradition, but its author had been a reactionary monarchist until the 1920s; the fraternal tradition sometimes evokes something of that doomed affect.

The second half of the book documents the ways in which Christian Democracy drew eclectically from both sides of this tradition. From the paternalists, it drew a vision of human rights and dignity centered on the private sphere of the patriarchal family, but, unlike some other neoliberal movements around the world, it tempered this turn with a surprising associationalism: encouraging strong roles for labor unions in economic management and workforce development. But even these substantial derivations from the fraternal tradition were often presented in forms derived from the paternalists. Thus the trade union policies were framed as support for the spending power of the heteronormative family as the cell of 
welfarism and economic development. This political framework was called the 'social market economy', as 'capitalism' still retained negative connotations of secularism and was generally disavowed. But, as Chappel notes, this ideology was insufficiently capacious, and excluded or occluded 'many forms of economic justice, a biting critique of consumerism, or a deep concern for the environment. Their focus on the nuclear, heteronormative family led to a neglect of nonnormative families, the rights of women, and kinds of suffering or social dislocation that could not be coded as familial' (p. 226). The book is important reading at a moment when the end of Angela Merkel's decades-long reign as the leader of the German Christian Democratic Union, arguably the most successful Christian Democratic party in Europe, is upon us. The politics of CDU figures like Merkel and Wolfgang Schäuble have done more to shape the politics of Europe as a whole than almost any other ideological tendency. It is well worth understanding where they come from: their theory of the state, of national culture, of faith, of pluralism and cosmopolitanism, of historical consciousness.

\section{III}

I will admit to a concern, upon ordering a review copy of Richard Jean So's Redlining Culture: A Data History of Racial Inequality and Postwar Fiction, that it might not earn its title. 'Redlining', understood rightly, is not merely segregation. A metaphor derived from the history of racist semi-intended consequences that followed federal interventions in US housing finance, redlining proper should refer to the almost vampiric effects that a selectively applied privilege or subsidy can have on those excluded. It's a familiar story. In the case of US housing, mortgage insurance offered in some, but not all, neighborhoods attracted investment to areas offered the insurance and made those without it less appealing. Because of widespread pre-existing segregation on racial lines, this pattern of valorization and devalorization significantly broadened racial wealth gaps. But the key point is that the boundary line itself produces a difference, and that difference, like the difference in electronegativity that generates an electric current, has a constitutive effect: it can do things in the world. The two sides of the line, though separated, interact with one another. My fear was that the kinds of quantitative methods So was applying to the history of postwar American publishing would not be sensitive enough to discern these phenomena. We would be left with a useful document of racial inequities in publishing lists and personnel, but little more. 
But the book overcame my skepticism. At its best moments, So's methodologies are indeed able to document the way that our institutions of publishing, book reviewing, and scholarly criticism have ossified or reified racialized entities like the 'Black Author' or 'Asian American Fiction' both as market phenomena and on the page. It is a formal argument, not just an institutional one. So builds his book around a number of linked corpuses of postwar fiction. In one of his more provocative chapters, So uses a corpus of texts coded for their belonging to overlapping bins of black-authored, bestselling, and prizewinning novels. He then asks the statistical analysis package $\mathrm{R}$ to identify distinctive traits that characterize these groups, so as to understand the place of black writers in the literary field. The point is not to assume that black-authored fiction is somehow different from bestselling or prizewinning fiction, but to interrogate the topology of the color line in American fiction. It thus becomes possible to use measurable formal traits, such as distinctive diction (bestsellers talk about airports an awful lot) or syntax (the frequency of adverbs becomes an important metric). The most striking illustrations of what So is able to do with this corpus are his close readings of texts that his predictive model misclassifies. I have always found Octavia Butler's work, for instance, so attentive to denaturalizing racial boundaries in its characterization that I have complained to students that the Beacon paperback edition of Kindred, with its cover illustration of a young black woman, spoils some part of the effect: the text itself is very careful to withhold disclosure of the protagonist's race. And so it was interesting to see that So's stylometric model had trouble identifying some of Butler's works as the work of a black author: 'Butler, in other words, exists on both sides of the machine's color line. She is doing something in her writing that subverts that line' (p. 132). But the white authors that the model expects to be black are at least as interesting: it is easy to see how a William Styron bestseller about a slave revolt might trip up the model, but the inclusion of Ben Marcus's Age of Wire and String surprised me, suggesting affinities I would not have anticipated.

Probably the most important headline finding comes from his most distant scale of analysis. There is a received narrative that the corporate consolidation of the publishing industry, largely under the umbrellas of the media conglomerates, has made space for a multicultural turn in American publishing. Thus, there is a kind of narrative of compensation: while the experimentalism and organic proximity to literary scenes that we associate with small and middle-sized publishers have been all but snuffed out by corporate consolidation, at least the scale of these new entities could give new opportunities and reach out to non-white authors and audiences. But 
So's analysis of his corpus suggests that this narrative may be overstated. Looking at a fifty-year histogram of Random House authors broken down by race, one can pick out the years when Toni Morrison began and ceased work as an editor at the publishing house. That is to say, while Random House's list remained overwhelmingly white — 97 percent overall—-the few deviations from that norm can be reliably attributed to the influence of a single person. This has a kind of grim irony to it. Cultural analytics scholarship is sometimes critiqued for a deindividuating tendency that tends to lose sight of the particularity and agency of individual participants and key artworks or documents in the phenomena under discussion. That can be true, but in this instance that impersonal emptiness is the emptiness of an auditorium in which Morrison's many contributions to American letters resonate and reverberate.

\section{Books Reviewed}

Bhattacharya, Tithi, ed., Social Reproduction Theory: Remapping Class, Recentering Oppression (London: Pluto Press, 2017). ISBN 9780745399898.

Chappel, James, Catholic Modern: The Challenge of Totalitarianism and the Remaking of the Church (Cambridge, MA: Harvard University Press, 2018). ISBN 9 780674972100.

Cooper, Melinda, Family Values: Between Neoliberalism and the New Social Conservatism (Princeton, NJ: Princeton University Press, 2017). ISBN 978193540 8345.

La Berge, Leigh Claire, Wages Against Artwork: Decommodified Labor and the Claims of Socially Engaged Art (Durham, NC: Duke University Press, 2019). ISBN 9 781478004820.

Lee, Pamela M., Think Tank Aesthetics: Midcentury Modernism, the Cold War, and the Neoliberal Present (Cambridge, MA: MIT Press, 2020). ISBN 9780262043526.

Sawyer, Stephen W., and Daniel Steinmetz-Jenkins, eds, Foucault, Neoliberalism and Beyond (London: Rowman \& Littlefield, 2019). ISBN 9781786603760.

So, Richard Jean, Redlining Culture: A Data History of Racial Inequality and Postwar Fiction (New York: Columbia University Press, 2021). ISBN 9780231197731.

\section{Journal Articles Reviewed}

Sotiris, Panagiotis, 'Thinking Beyond the Lockdown: On the Possibility of a Democratic Biopolitics', Historical Materialism, 28.3 (2020), 3-38. 


\section{References}

Bennett, Eric, Workshops of Empire: Stegner, Engle, and American Creative Writing During the Cold War (lowa City: University of lowa Press, 2015).

Coviello, Peter, 'Our Man Foucault', Bully Bloggers, 29 June 2020; <https://bully bloggers.wordpress.com/2020/06/29/our-man-foucault-by-peter-coviello/> [accessed?].

Costa Dalla, Mariarosa, and Selma James, The Power of Women and the Subversion of the Community (Bristol: Falling Wall Press, 1975).

Dwyer, Rachel E., 'The Care Economy? Gender, Economic Restructuring, and Job Polarization in the U.S. Labor Market', American Sociological Review, 78.3 (2013), 390-416.

Ferguson, Susan, Women and Work: Feminism, Labour, and Social Reproduction (London: Pluto Press, 2019).

Foucault, Michel, Lectures at the Collège de France, ed. by A. I. Davidson, 13 vols (London: Palgrave Macmillan, 2005-19).

Moreton, Bethany, 'Our Lady of Mont Pelerin: The "Navarra School" of Catholic Neoliberalism', Capitalism: A Journal of History and Economics, 2.1 (Winter 2021), 88-153.

Munro, Kirsten, "'Social Reproduction Theory," Social Reproduction, and Household Production', Science \& Society, 83.4 (Oct. 2019), 451-68.

Puar, Jasbir, The Right to Maim: Debility, Capacity, Disability (Durham, NC: Duke University Press, 2017).

Saunders, Frances Stonor, The Cultural Cold War: The CIA and the World of Arts and Letters (New York: The New Press, 2001).

Winant, Gabriel, The Next Shift: The Fall of Industry and the Rise of Health Care in Rust Belt America (Cambridge, MA: Harvard University Press, 2021).

Zamora, Daniel, and Michael C. Behrent, Foucault and Neoliberalism (Cambridge: Polity, 2015).

Zamora, Daniel, and Mitchell Dean, The Last Man Takes LSD: Foucault and the End of Revolution (London: Verso, forthcoming). 